\title{
A Multidecade Experiment Shows that Fertilization by Salmon Carcasses Enhanced Tree Growth in the Riparian Zone
}

Thomas P. Quinn

University of Washington

Helfield M. James

Western Washington University, james.helfield@wwu.edu

Catherine S. Austin

University of Washington

Rachel A. Hovel

University of Washington

Andrew Godard Bunn

Western Washington University, andy.bunn@wwu.edu

Follow this and additional works at: https://cedar.wwu.edu/esci_facpubs

Part of the Environmental Sciences Commons, and the Marine Biology Commons

\section{Recommended Citation}

Quinn, T. P., Helfield, J. M., Austin, C. S., Hovel, R. A. and Bunn, A. G. (2018), A multidecade experiment shows that fertilization by salmon carcasses enhanced tree growth in the riparian zone. Ecology, 99: 2433-2441. doi:10.1002/ecy.2453

This Article is brought to you for free and open access by the Environmental Sciences at Western CEDAR. It has been accepted for inclusion in Environmental Sciences Faculty and Staff Publications by an authorized administrator of Western CEDAR. For more information, please contact westerncedar@wwu.edu. 


\title{
A multidecade experiment shows that fertilization by salmon carcasses enhanced tree growth in the riparian zone
}

\author{
Thomas P. Quinn, ${ }^{1,4}$ James M. Helfield, $^{2}$ Catherine S. Austin, ${ }^{1}$ Rachel A. Hovel (iD), ${ }^{1,3}$ And Andrew G. Bunn (iD 2 \\ ${ }^{1}$ School of Aquatic and Fishery Sciences, University of Washington, Box 355020, Seattle, Washington 98195 USA \\ ${ }^{2}$ Department of Environmental Sciences, Huxley College of the Environment, Western Washington University, MS 9181 , \\ Bellingham, Washington 98225 USA
}

\begin{abstract}
As they return to spawn and die in their natal streams, anadromous, semelparous fishes such as Pacific salmon import marine-derived nutrients to otherwise nutrient-poor freshwater and riparian ecosystems. Diverse organisms exploit this resource, and previous studies have indicated that riparian tree growth may be enhanced by such marine-derived nutrients. However, these studies were largely inferential and did not account for all factors affecting tree growth. As an experimental test of the contribution of carcasses to tree growth, for $20 \mathrm{yr}$, we systematically deposited all sockeye salmon (Oncorhynchus nerka) carcasses (217,055 individual salmon) in the riparian zone on one bank of a 2$\mathrm{km}$-long stream in southwestern Alaska, reducing carcass accumulation on one bank and enhancing it on the other. After accounting for partial consumption and movement of carcasses by brown bears (Ursus arctos) and variation in salmon abundance and body size, we estimated that $267,620 \mathrm{~kg}$ of salmon were deposited on the enhanced bank and $45,200 \mathrm{~kg}$ on the depleted bank over the $20 \mathrm{yr}$, for a 5.9-fold difference in total mass. In 2016, we sampled needles of 84 white spruce trees (Picea glauca) the dominant riparian tree species, for foliar nitrogen $(\mathrm{N})$ content and stable isotope ratios $\left(\delta^{15} \mathrm{~N}\right)$, and took core samples for annual growth increments. Stable isotope analysis indicated that marine-derived $\mathrm{N}$ was incorporated into the new growth of the trees on the enhanced bank. Analysis of tree cores indicated that in the two decades prior to our enhancement experiment, trees on the south-facing (subsequently the depleted) bank grew faster than those on the north-facing (later enhanced) bank. This difference was reduced significantly during the two decades of fertilization, indicating an effect of the carcass transfer experiment against the background of other factors affecting tree growth.
\end{abstract}

Key words: bear predation; fertilization; marine-derived nutrients; nitrogen; salmon; stable isotopes; tree growth; white spruce.

\section{INTRODUCTION}

Over the past several decades, increasing evidence has indicated that the return of anadromous, semelparous fishes to coastal rivers can bring great quantities of marine-derived nutrients to otherwise nutrient-poor freshwater and riparian ecosystems (Janetski et al. 2009, Naiman et al. 2009). These nutrients are transported upriver during spawning migrations by clupeids such as American shad (Alosa sapidissima) and alewife (A. pseudoharengus; MacAvoy et al. 2009, Twining et al. 2017), petromyzontids (Nislow and Kynard 2009), and Pacific salmon of the genus Oncorhynchus (Kline et al. 1990, Bilby et al. 1996, Janetski et al. 2009). In many streams of the Pacific Rim, these salmon (often weighing several kilograms each) can reach high densities (commonly over 1,000 fish per ha of stream area; Quinn et al. 2017), and their inevitable death after reproduction provides food for a very wide range of aquatic and terrestrial organisms including insects (Meehan et al. 2005, Winder et al. 2005) and birds (Hunt et al. 1992, Field and Reynolds 2011, 2013). Among the mammals, bears are conspicuous for their predation on salmon and transportation of carcasses

Manuscript received 16 April 2018; revised 1 June 2018; accepted 18 June 2018. Corresponding Editor: Sara Vicca.

${ }^{3}$ Present address: Department of Biology, University of Maine, Farmington, Maine 04938 USA

${ }^{4}$ E-mail: tquinn@uw.edu
(Hilderbrand et al. 1999b, Van Daele et al. 2013), but many other species also feed on salmon (Cederholm et al. 1989). Indeed, Pacific salmon have been referred to as keystone species in vertebrate communities of the Pacific Rim (Willson and Halupka 1995).

The importance of salmon-derived nutrients has been demonstrated with a variety of methods, including the use of naturally occurring stable isotopes of nitrogen $(\mathrm{N})$ and carbon $(\mathrm{C})$. The heavier stable isotopes of these elements $\left({ }^{15} \mathrm{~N}\right.$ and ${ }^{13} \mathrm{C}$ ) are generally more abundant in marine compared to freshwater systems (Schoeninger et al. 1983, Owens 1987), allowing these elements to be tracked as they are transferred from salmon to freshwater ecosystems. Isotopic analyses indicate that marine-derived $\mathrm{N}(\mathrm{MDN})$ is incorporated into foliage (Bilby et al. 1996, Ben-David et al. 1998, Hilderbrand et al. 1999a) and soils (Reimchen et al. 2003, Bartz and Naiman 2005) in riparian zones adjacent to spawning streams. Foliar nutrient concentrations tend to be higher in plants receiving inputs of salmon-borne nutrients (Helfield and Naiman 2001, 2002, Bilby et al. 2003, Mathewson et al. 2003), but this is not always the case (BenDavid et al. 1998, Bartz and Naiman 2005, Drake et al. 2006). The weight of evidence suggests that riparian plants are enriched by salmon-borne marine nutrients in areas with dense spawning aggregations, but this evidence is largely inferred from broad comparisons of watersheds with and without salmon, and as such might not account for any biogeochemical process unrelated to salmon that can affect 
nutrient dynamics and isotopic signatures in plants (Kirchhoff 2003, Pinay et al. 2003).

The evidence is also compelling but somewhat equivocal regarding growth responses of riparian trees. Studies of Sitka spruce (Picea sitchensis) in southeastern Alaska (Helfield and Naiman 2001) and white spruce (P. glauca) in southwestern Alaska (Helfield and Naiman 2002) indicate enhanced basal area growth in trees growing near salmonbearing streams relative to those growing at comparable distances from streams that are inaccessible to salmon. The design of these studies has been criticized for not accounting for the potentially confounding influence of variations in soil characteristics among watersheds (Kirchhoff 2003). At finer spatial scales, Reimchen and Fox (2013) reported that growth rates of Sitka spruce were influenced by variations in salmon carcass density and also by temperature within a small salmon-bearing watershed in British Columbia. In terms of temporal relationships, dendrochronological analyses have indicated significant correlations between annual salmon escapement and riparian tree ring growth at some sites, but not at others. Drake et al. (2002) reported significant correlations in coastal temperate rainforests of southeastern Alaska, but not in boreal forests of southwestern Alaska. Similarly, Drake and Naiman (2007) reported significant correlations between salmon abundance and tree growth at five of nine sites in Oregon, British Columbia, and southeastern Alaska.

To elucidate the extent to which nutrients from salmon carcasses enhance tree growth, we report here the results of a long-term fertilization experiment on a small watershed in southwestern Alaska. For $20 \mathrm{yr}$, salmon carcasses were thrown to only one bank of a small stream, depleting carcass density on one bank and enhancing it on the other. We predicted that trees on the bank enhanced with carcasses would show higher levels of marine-derived nutrients in their foliage and higher growth rates during the 20 -yr experimental period, relative to growth prior to treatment.

\section{Materials AND Methods}

\section{Site description and field experiment}

The study was conducted in Hansen Creek, a small (averag: $4 \mathrm{~m}$ wide, $10 \mathrm{~cm}$ deep, $0.1 \mathrm{~m}^{3} / \mathrm{s}$ ) stream flowing $2 \mathrm{~km}$ from a spring-fed beaver pond into Lake Aleknagik, in the Wood River system of Bristol Bay, southwestern Alaska, USA $\left(59^{\circ} 19^{\prime} \mathrm{N}, 158^{\circ} 42^{\prime} \mathrm{W}\right)$. The area is in a transitional climatic zone, with maritime as well as continental influences affecting weather patterns. Average summer temperatures range from $6^{\circ} \mathrm{C}$ to $20^{\circ} \mathrm{C}$, and average winter temperatures range from $-15^{\circ} \mathrm{C}$ to $-6^{\circ} \mathrm{C}$. Annual precipitation ranges from 250 to $340 \mathrm{~cm}$, of which $200-250 \mathrm{~cm}$ falls as snow in winter (Hartman and Johnson 1984). The vegetation surrounding Hansen Creek is a boreal forest association of white spruce and paper birch (Betula papyrifera) with willow (Salix spp.) and cottongrass (Eriophorum spp.) in the understory. Unlike some of the watersheds in this region, Hansen Creek has very little alder (Alnus crispa), which can provide a significant source of nitrogen through symbiotic fixation of atmospheric $\mathrm{N}_{2}$, thereby confounding the importance of MDN (Helfield and Naiman 2002) for riparian growth. This natural feature makes Hansen Creek a good system in which to examine the effects of salmon on trees.

Despite its small size, Hansen Creek supports a dense population of spawning adult sockeye salmon (Oncorhynchus nerka) with an average annual escapement (i.e., the number of salmon that return to the spawning grounds) of 6,148 from 1977 through 1996, and 10,853 from 1997 through 2016 (Appendix S1). These salmon are subject to heavy predation by brown bears (Ursus arctos), and many aspects of this relationship have been studied on Hansen Creek (Ruggerone et al. 2000, Quinn et al. 2009, 2014a). Extensive surveys over many decades have not recorded any Pacific salmon species other than sockeye (Pess et al. 2014), and sampling of bear hair for DNA has revealed only brown, not black (U. americanus) bears (Quinn et al. 2014b). The beaver pond and generally low-gradient topography result in very stable flows and, during the salmon spawning season, the stream does not overtop its banks. Therefore, unlike some streams (Ben-David et al. 1998), high flows do not distribute salmon carcasses into the riparian zone. These features make this system simple in terms of the source of marine-derived nutrients (sockeye salmon) and the main natural vector into the forest (brown bears), though some hyporheic transport may also occur (O'Keefe and Edwards 2002). A significant proportion of Hansen Creek sockeye are killed or scavenged and transported to the riparian zone by bears (Quinn et al. 2009), and trees growing close to the stream receive significant inputs of salmon-borne, marine-derived nutrients (Helfield and Naiman 2002).

Hansen Creek has been the focus of intensive studies of brown bear predation on sockeye salmon (Cunningham et al. 2013, Quinn et al. 2014a) and surveyed on foot daily throughout the spawning season (approximately 20 July to 20 August) since 1990 and less intensively in earlier years. To prevent double-counting of carcasses, surveyors throw them from the stream $\sim 5 \mathrm{~m}$ into the riparian zone after the carcasses have been counted and categorized (cause of death and extent of consumption by bears). Since 1997, all carcasses have been deliberately thrown into the forest on the left (north-facing) bank of the stream, making this a beforeafter-treatment study with respect to the possible role of salmon-derived nutrients on tree growth.

We first estimated fish biomass available to each streambank during the 20-yr carcass manipulation period (1997 through 2016). We determined the total number of sockeye salmon in Hansen Creek each year as the total number of dead salmon recorded and removed from the stream plus the number still alive on the last survey date (average $=6 \%$ of the total; Quinn et al. 2014a). Those alive after our surveys ended were assigned evenly between both banks. We then estimated the mass of salmon deposited, based on sexspecific body length-mass regressions ( $R^{2}$ range $0.37-0.89$, all $P<0.001$, Table 1) derived from data on Hansen Creek sockeye salmon that had died of senescence. We assumed that these relationships did not change over time but used year-specific length data. If all salmon died of senescence, these mass data would suffice but many salmon were killed by bears, and killing and scavenging of carcasses by Glaucous-winged Gulls is also common (Quinn and Buck 2001). Accordingly, for each year, we used separate length-mass relationships for the salmon partially consumed by bears 
TABLE 1. Sex-specific (f, females; m, males) body length-mass regression relationships for sockeye salmon in Hansen Creek, Alaska, based on empirical data (1997-2016) with causes of mortality (bears, stranding, senescence, and gulls) calculated separately $(P<0.001$ in all cases).

\begin{tabular}{lrcr}
\hline \hline Status (sex) & \multicolumn{1}{c}{$N$} & Model selected length-mass relationships & Multiple $R^{2}$ \\
\hline Alive (f) & 823 & $4.289 \times 10^{1}-\left(2.774 \times 10^{-1}\right) x+\left(6.030 \times 10^{-4}\right) x^{2}-\left(4.174 \times 10^{-7}\right) x^{3}$ & 0.579 \\
Alive (m) & 1,306 & $\left(2.028-1.233 \times 10^{-2}\right) x+\left(2.888 \times 10^{-5}\right) x^{2}$ & 0.749 \\
Bear-killed (f) & 896 & $-2.1568308+0.0080697 x$ & 0.374 \\
Bear-killed (m) & 720 & $2.274 \times 10^{1}-\left(1.727 \times 10^{-1}\right) x+\left(4.259 \times 10^{-4}\right) x^{2}-\left(3.223 \times 10^{-7}\right) x^{3}$ & 0.536 \\
Stranded (f) & 344 & $5.879-\left(3.135 \times 10^{-2}\right) x+\left(5.098 \times 10^{-5}\right) x^{2}$ & 0.819 \\
Stranded (m) & 268 & $9.237-\left(4.658 \times 10^{-2}\right) x+\left(6.846 \times 10^{-5}\right) x^{2}$ & 0.893 \\
Senescent (f) & 221 & $9.139 \times 10^{-1}-\left(7.796 \times 10^{-3}\right) x+\left(2.206 \times 10^{-5}\right) x^{2}$ & 0.718 \\
Senescent (m) & 119 & $7.586 \times 10^{-1}-\left(7.854 \times 10^{-3}\right) x+\left(2.409 \times 10^{-5}\right) x^{2}$ & 0.889 \\
Gull-killed (f) & 66 & $1.980-\left(1.313 \times 10^{-2}\right) x+\left(2.736 \times 10^{-5}\right) x^{2}$ & 0.571 \\
Gull-killed (m) & 30 & $-1.8689992+0.0080590 x$ & 0.860 \\
\hline
\end{tabular}

and by gulls based on empirical data (e.g., length of fish killed by bears 1997-2016, $N=21,809$; length of senescent fish 1997-2016, $N=19,184$, relationships are reported in Table 1). Combined with counts of partially consumed fish, these data were used to reduce our estimates of the mass thrown into the forest as appropriate. To account for the fact that bears commonly consumed only a fraction of the carcass, we estimated the average mass of salmon across different patterns of consumption (Gende et al. 2001) and applied these values to salmon from which, for example, the bear had consumed the belly and eggs, the dorsal hump, or the whole body, leaving only the head. Salmon that became stranded in shallow water as they migrated upstream and died (Quinn and Buck 2001) or died of stress during periods of low dissolved oxygen (Tillotson and Quinn 2017) were categorized separately, and their mass was estimated from length-mass relationships based on sockeye salmon sampled prior to entering Hansen Creek.

Salmon that were killed by bears and deposited within $\sim 5 \mathrm{~m}$ of the stream on the right ("depleted") bank were moved to the left ("enhanced") bank but the more distant riparian zone was not systematically surveyed. Tagging studies indicated that some of the salmon killed by bears are transported beyond the normal survey area in Hansen Creek (Quinn et al. 2009) and we assumed that these carcasses were evenly distributed on both banks of the stream. The fraction of the total run moved by bears varies among years so we used annual estimates from tagging studies (Quinn et al. 2009, and additional T. P. Quinn, unpublished data) to estimate the number and biomass of these salmon (not actually seen as carcasses) that were likely killed and transported, and divided that mass evenly between both banks.

Analysis of tree growth spanned $40 \mathrm{yr}$, including the $20 \mathrm{yr}$ of carcass manipulation (1997-2016) and the previous $20 \mathrm{yr}$ (1977-1996). Consequently, we needed yearly estimates of salmon abundance from 1977 onward but prior to 1990 the salmon surveying was less extensive, with typically only a single survey each year. Counts in these years were corrected to include the salmon that arrived after the survey by constructing daily cumulative run curves for each year using the complete post-1990 data (i.e., percentage of the annual total in the stream by 31 July, 1 August, etc.) and then applying these values to expand the count on the actual day of the survey in each of the earlier years. The once-yearly surveys in 1977 through 1989 averaged 2,582 sockeye salmon and were expanded to an average total yearly run size of 4,281, so the single surveys averaged $60 \%$ of the estimated total (Quinn et al. 2014a). These estimated annual abundance values were multiplied by the average mass of salmon (including those dying of senescence and those killed and scavenged) in the more recent years and divided evenly between the two banks of the stream (Appendix S1). These estimates were based on the assumptions that spawning timing and the relationship between abundance of salmon and proportion killed were not different from the recent decades. Analysis of spawning timing back to 1990 revealed some year to year variation but no trend (T. P. Quinn, unpublished analysis), so the first assumption seems valid. There was no reason to expect that bear predation would change but we cannot rule this out. Regardless, in these years, all salmon were assigned equally to the two banks so any violation of the assumptions would only affect the total mass, not the distribution.

After calculating total salmon biomass, we estimated the mass of $\mathrm{N}$ and phosphorus (P) from the salmon carcasses on each bank of the stream. Larkin and Slaney (1997) reported that salmon carcasses were $3.04 \% \mathrm{~N}$ and $0.36 \% \mathrm{P}$ by wet mass but these values were generic, not specific to species, sex, or condition of the fish. Gende et al. (2004) sampled adult pink (O. gorbuscha) and chum (O. keta) salmon and reported separate values for both fresh (unspawned) and senescent dead salmon. Mass-specific $\mathrm{N}$ and $\mathrm{P}$ did not differ between species or sexes, and averaged $3.28 \% \mathrm{~N}$ for fresh salmon and $2.45 \% \mathrm{~N}$ for senescent dead salmon, and $0.47 \% \mathrm{P}$ in fresh salmon and $0.42 \% \mathrm{P}$ in senescent dead salmon. The salmon killed by bears and gulls vary in condition, so we used the mean values between fresh and senescent fish $(2.87 \% \mathrm{~N}$ and $0.45 \% \mathrm{P})$ as broadly representative. These values are similar to those reported by Larkin and Slaney (1997) so, for our purposes, we used 3.0\% $\mathrm{N}$ and $0.4 \% \mathrm{P}$, and multiplied them by the mass of salmon tissue to estimate the fertilization of each bank in the pre- and posttreatment periods.

\section{Tree sampling}

To determine whether there were differences in forest community composition between the two banks that might influence our results, in August 2016, we established 31 
interrupted belt transects on each bank, running parallel to the direction of streamflow, spaced $50 \mathrm{~m}$ apart from each other. Each transect was $20 \mathrm{~m}$ long $\times 5 \mathrm{~m}$ wide, encompassing the area closest to the stream channel. One transect was shortened to $8 \mathrm{~m}$ because the remaining $12 \mathrm{~m}$ encompassed a steep bank where vegetation was $>5 \mathrm{~m}$ above the stream channel. Within each transect, we recorded the species and diameter at breast height $(\mathrm{DBH}$, standardized to 4.5 feet $[1.37 \mathrm{~m}]$ ) of all woody vegetation $>10 \mathrm{~cm} \mathrm{DBH}$, and noted whether the tree was living or dead. We then calculated stem density as the total number of trees within each transect divided by the transect area (e.g., $100 \mathrm{~m}^{2}$ ), and basal area density as the sum of the basal areas of all trees within the transect divided by the transect area. The basal area of each tree was calculated using $\mathrm{DBH}$ measurements (i.e., basal area $\left.=\pi \times(\mathrm{DBH} / 2)^{2}\right)$.

To compare nutrient enrichment and growth between banks, we sampled every fifth living white spruce tree with $\mathrm{DBH}>10 \mathrm{~cm}$ within $5 \mathrm{~m}$ of the wetted stream channel on both banks. This size criterion was designed to sample trees that were old enough to have been mature during the 20 -yr period prior to carcass manipulation. In total, 84 spruce trees were sampled, 44 on the enhanced bank and 40 on the depleted bank. For each tree sampled, we recorded the $\mathrm{DBH}$, bank, distance from the stream edge, and distance along the stream from Lake Aleknagik. We also recorded the presence or absence of bear middens (i.e., areas used consistently for feeding on salmon by bears, identified by matted grass and recurrent deposition of bear feces and partially eaten salmon carcasses) within $5 \mathrm{~m}$ because MDN enrichment tends to be greater at such areas (Helfield and Naiman 2002).

For each spruce tree sampled, a 3-5 g wet mass sample of new annual needle growth at unshaded branch tips at a height of 1-2 $\mathrm{m}$ was collected and immediately placed into a new plastic bag, frozen within $5 \mathrm{~h}$ of collection, and kept frozen until subsequent processing. Needle tissue samples were then dried at $60^{\circ} \mathrm{C}$ for at least $48 \mathrm{~h}$ and ground into uniform powder $(<212 \mu \mathrm{m})$ using a ball mill. Samples were then analyzed for $\mathrm{N}$ content and stable isotope ratios $\left({ }^{15} \mathrm{~N}:{ }^{14} \mathrm{~N}\right)$ using a Costech Elemental Analyzer, Conflo III, MAT253 for continuous flow-based measurements at University of Washington's IsoLab. Reference materials used for assessment and calibration were glutamic acid and Bristol Bay sockeye salmon. Stable isotope ratios were expressed as $\delta^{15} \mathrm{~N}$ values, which represent the per mil deviation in ${ }^{15} \mathrm{~N}$ abundance from atmospheric $\mathrm{N}_{2}$, the recognized isotopic standard (Schoeninger et al. 1983, Owens 1987).

To characterize white spruce growth rates, we collected increment core samples from 80 of the study trees (43 on the enhanced bank and 37 on the depleted bank). Cores were taken at breast height from the bole using a $5 \mathrm{~mm}$ diameter manual borer. Each core was prepared for analysis following standard dendrochronological protocols (Phipps 1985), including air drying, gluing to mounting boards, and sanding with progressively finer grit. Cores were then crossdated and absolute dates (with annual resolution) were assigned to the growth rings. Ring widths were measured to the nearest $0.01 \mathrm{~mm}$ using an Acu-Rite SENC150 precision glass scale linear encoder with digital output (Chaney Instrument, Lake Geneva, Wisconsin, USA), connected to a dissecting microscope with video display. Ring widths were converted to annual basal area increments by the following equation:

$$
\mathrm{BAI}=w \times 2 \pi r
$$

where BAI is annual basal area increment $\left(\mathrm{mm}^{2}\right), w$ is annual ring width $(\mathrm{mm})$, and $r$ is the radius of the tree $(\mathrm{mm})$ minus bark width, calculated as the cumulative total of all previous years' ring widths. These measurements were separated into pre-experiment and post-experiment years based on growth ring dating.

\section{Data analysis}

Observed $\delta^{15} \mathrm{~N}$ values were converted to MDN percentages using a two-source mixing model (Kline et al. 1990, Bilby et al. 1996) which calculates MDN percentage as follows:

$$
\% \mathrm{MDN}=((\mathrm{SAM}-\mathrm{TEM}) /(\mathrm{MEM}-\mathrm{TEM})) \times 100
$$

where $\% \mathrm{MDN}$ is the percentage of MDN in a given sample, SAM is the observed $\delta^{15} \mathrm{~N}$ value of the sample, TEM is the terrestrial end member (i.e., $\delta^{15} \mathrm{~N}$ value representing $0 \%$ MDN), and MEM is the marine end member (i.e., $\delta^{15} \mathrm{~N}$ value representing $100 \% \mathrm{MDN}$ ). In this study, TEM was the mean $\delta^{15} \mathrm{~N}$ of white spruce foliage $>50 \mathrm{~m}$ from spawning streams $(-1.74 \pm 0.64)$, and MEM was the mean $\delta^{15} \mathrm{~N}$ of sockeye salmon carcass tissue $(12.62 \pm 0.31$; mean $\pm 95 \% \mathrm{CI})$, using values for both as reported by Helfield and Naiman (2002). The model assumes that isotopic fractionation associated with $\mathrm{N}$ uptake is negligible, as is likely the case where $\mathrm{N}$ is limiting (Nadelhoffer and Fry 1994). Two-tailed unpaired Welch's $t$ tests were used to test for differences in the $\mathrm{C}: \mathrm{N}$ ratios in spruce tree needle tissue between stream banks. Multiple linear regression was used to identify influences on the $\mathrm{C}: \mathrm{N}$ ratio in spruce tissue from among the variables tree $\mathrm{DBH}$, salmon carcass enhancement status, presence of a nearby bear midden, distance from wetted channel, and distance from mouth of stream. Two-tailed unpaired Welch's $t$ tests were also used to test for differences in spruce tissue $\delta^{15} \mathrm{~N}$ between stream banks. Multiple linear regression with stepwise AIC was used to identify which variables (enhancement status, tree distance from wetted channel, tree DBH, distance from stream mouth, and presence of a nearby bear midden) influenced foliar values of $\delta^{15} \mathrm{~N}$. All statistical analyses were conducted in $\mathrm{R}$ (R Core Team 2015).

To assess differences in tree growth, we compared median BAI values of trees on both banks during the 20 -yr carcass manipulation period (1997-2016) and the previous $20 \mathrm{yr}$ (1977-1996). We used 10,000 bootstrap replicates to determine bias-corrected and accelerated (BCa) 99\% confidence intervals for the median values. We used the $\mathrm{BCa}$ approach to correct for skewness in the distribution of the estimates, but preliminary analyses yielded similar results using the bootstrap percentile intervals. Similarly, results were consistent across variations in the number of replicates and when using mean instead of median BAI values. We did not explicitly incorporate the effect of variation in climatic factors on tree growth over the course of the experimental time frame, since we assumed that both banks of the stream 
experienced temperature and precipitation fluctuations in the same way.

\section{RESULTS}

\section{Forest composition}

The enhanced and depleted banks did not differ significantly in stem density (79.1 vs. 127.0 trees/ha, $t=1.27$, $P=0.21)$ or in basal area density $\left(404.9\right.$ vs. $235.3 \mathrm{~m}^{2} / \mathrm{ha}$, $t=0.72, P=0.47$ ) based on unpaired Welch's $t$ tests. In addition, the overstory species composition was virtually identical on the enhanced and depleted banks of the stream: $61.3 \%$ vs. $62.2 \%$ white spruce, $37.2 \%$ vs. $37.0 \%$ paper birch, and $1.6 \%$ vs. $0.8 \%$ willow.

\section{Carcass deposition}

We estimated that in the $20 \mathrm{yr}$ prior to the treatment period, Hansen Creek averaged 6,148 adult sockeye salmon in total, with $4,546 \mathrm{~kg}$ of salmon tissue for each bank of the stream (Appendix S1). These salmon were estimated to have contributed $136.4 \mathrm{~kg}$ of $\mathrm{N}$ and $18.2 \mathrm{~kg}$ of $\mathrm{P}$ to each bank annually in this period. Over the succeeding two decades of the manipulation, there was a 5.9-fold difference in total carcass mass between the two banks (mean 13,381 kg on the enhanced bank and 2,260 kg on the depleted bank), and the annual difference averaged 9.6-fold. Average annual $\mathrm{N}$ contributions from these carcasses to the enhanced and depleted bank were 401.4 and $67.8 \mathrm{~kg}$, respectively. Corresponding P contributions were 53.5 and $9.0 \mathrm{~kg}$. The increase in total deposition in the experimental period resulted from the greater numbers of salmon that returned to Hansen Creek in the most recent two decades compared to the previous period.

\section{Nutrient enrichment}

Foliar percent $\mathrm{C}: \mathrm{N}$ varied by tree $\mathrm{DBH}\left(\mathrm{F}_{1,82}=5.82\right.$, $P=0.02)$, but did not significantly differ between banks ( $F_{1,82}=3.15, P=0.08$; Fig. 1$)$. On the enhanced bank, mean C:N was 44.0 (95\% CI: 40.1, 44.3), compared to 45.9 (95\% CI: 41.9, 46.1) on the depleted bank (Welch's $t$ test, $\left.t_{84(2)}=-1.76, P=0.08\right)$. Multiple linear regression and stepwise AIC model selection found no significant effects of any other variables (tree distance from wetted channel, enrichment status (i.e., bank), distance from stream mouth, and presence of a nearby bear midden) on $\mathrm{C}: \mathrm{N}$. The needles on the enhanced bank had significantly higher $\delta^{15} \mathrm{~N}$ (mean 10.7; $95 \%$ CI: $7.5,16.2)$ than did those on the depleted bank (mean 6.4 ; $95 \%$ CI: $3.2,11.9 ; t_{84(2)}=7.65, P<0.0001$ ). Linear models indicated that needle $\delta^{15} \mathrm{~N}$ varied only with enrichment status (i.e., enhanced vs. depleted bank); multiple linear regression and stepwise AIC model selection found no significant effects of the remaining variables: tree distance from wetted channel, tree $\mathrm{DBH}$, distance from stream mouth, and presence of a nearby bear midden (Table 2). The two-source mixing model indicated that white spruce tree needles on the enhanced bank of Hansen Creek comprised a mean of approximately $86.8 \% \pm 19.6 \%$ (mean $\pm 95 \%$ CI $)$ MDN, vs. $56.8 \% \pm 10.7 \%$ on the depleted bank.

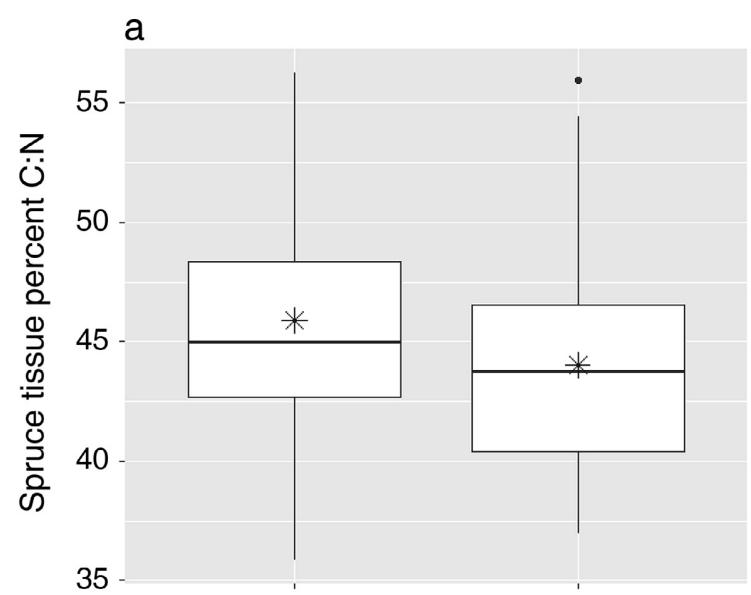

b

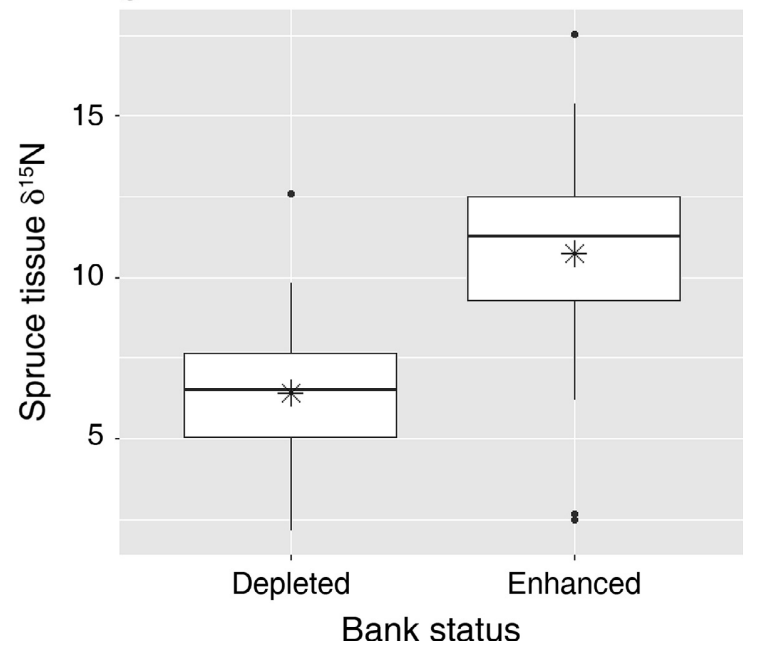

FIG. 1. Median (line) and mean (star), with boxes representing quartiles, whiskers representing the lowest and highest data points within 1.5 times the interquartile range of the lower and higher quartiles, respectively, and points representing the outliers. (a) The ratio of percent carbon to percent nitrogen in white spruce (Picea glauca) needles from 84 trees sampled in August 2016 from salmoncarcass-depleted and salmon-carcass-enhanced stream banks of Hansen Creek, Alaska, USA and (b) the values for tree tissue $\delta^{15} \mathrm{~N}$ for each bank.

\section{Tree growth}

Prior to carcass manipulation, spruce growth rates were lower on the enhanced bank than on the depleted bank (Fig. 2). During the carcass manipulation period, the enhanced bank showed an increase in median BAI from 307 to $407 \mathrm{~mm}^{2}$ with no overlap in the bootstrapped confidence intervals. During the same period, median BAI on the depleted bank increased from 476 to $507 \mathrm{~mm}^{2}$ but with significant overlap in the confidence intervals. For trees on the enhanced bank, the $99 \%$ confidence interval for the post- minus pretreatment difference in medians did not span zero (calculated difference between time periods was $100 \mathrm{~mm}^{2}$ with $99 \%$ CI of 35,168 ), indicating that median BAI was greater during the carcass manipulation period than in the previous $20 \mathrm{yr}$. This change was not observed on the depleted bank (calculated difference was $31 \mathrm{~mm}^{2}$ with $99 \%$ CI of $-70,122$ ), indicating no difference in median BAI between the two periods there. 
TABLE 2. Model selection for $\delta^{15} \mathrm{~N}$ patterns in white spruce needles sampled from trees within $5 \mathrm{~m}$ of the wetted channel in Hansen Creek, Alaska, in 2016, including $F$ statistic (Total $F$ ), degrees of freedom (df), adjusted $R^{2}$, Akaike's information criterion (AIC), and the difference between the given model and the best performing model $(\triangle \mathrm{AIC})$.

\begin{tabular}{lcccc}
\hline \hline Model & Total $F$ & df & Adj. $R^{2}$ & AIC \\
\hline$\delta^{15} \mathrm{~N} \sim$ Distance + DBH + Bank + Section + Midden & 10.14 & 6,77 & 0.40 & 409.54 \\
$\delta^{15} \mathrm{~N} \sim$ Distance + DBH + Bank + Section & 12.33 & 5,78 & 0.41 & 407.55 \\
$\delta^{15} \mathrm{~N} \sim$ DBH + Bank + Section & 15.57 & 4,79 & 0.41 & 405.64 \\
$\delta^{15} \mathrm{~N} \sim$ Bank + Section & 20.96 & 3,80 & 0.42 & 403.74 \\
$\delta^{15} \mathrm{~N} \sim$ Bank & 56.71 & 1,82 & 0.40 & 404.31 \\
\hline
\end{tabular}

Notes: Observed $\delta^{15} \mathrm{~N}$ values were modeled as a function of tree distance from wetted channel, diameter at breast height (DBH) of sampled tree, location on experimental bank (i.e., enhanced or depleted), binned distance from stream mouth denoted "section," and the presence of a bear midden within $5 \mathrm{~m}$ of the sampled tree. The inclusion of section and DBH did not improve the $\Delta \mathrm{AIC}>2$, making the most parsimonious model the simplest.

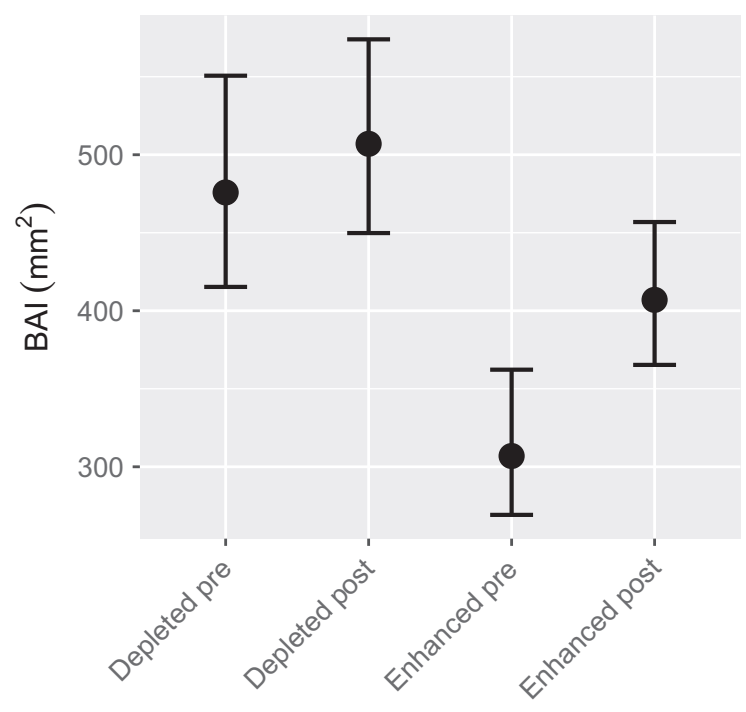

FIG. 2. Median basal area increment (BAI) of white spruce trees on the carcass-enhanced (left) and carcass-depleted (right) banks of Hansen Creek during the 20-yr pretreatment period (1976-1996) and the 20-yr carcass manipulation period (1997-2016). Bars represent $99 \%$ confidence intervals of the medians, based on 10,000 bootstrapped replicates.

\section{Discussion}

As predicted, the analysis of $\mathrm{N}$ stable isotope values of white spruce needles collected in 2016 revealed a significant difference between the two banks of Hansen Creek, consistent with fertilization from salmon carcasses. The significantly higher foliar $\% \mathrm{MDN}$ on the enhanced bank indicated a relatively quick response (i.e., within two decades), consistent with the findings of previous work indicating that salmon carcasses can deliver pulses of bioavailable $\mathrm{N}$ to forest soils within months of deposition (Drake et al. 2005). The foliar $\% \mathrm{MDN}$ estimates in this study are consistent with values obtained by Helfield and Naiman (2002). The reported value in that paper, $24 \%$, included spruce growing at distances up to $100 \mathrm{~m}$ from the stream and also included spruce at alder-influenced sites, but data from trees growing within $5 \mathrm{~m}$ of spawning streams at sites without alder indicated an average of approximately 52\% MDN (J. Helfield, unpublished data). This value is comparable to the $57 \%$ MDN indicated on the depleted bank in this study, which was exposed to natural levels of carcass additions through 1996. The fact that trees on the depleted bank still had such high $\% \mathrm{MDN}$ values after $20 \mathrm{yr}$ of artificial carcass depletion suggests that the foliar $\delta^{15} \mathrm{~N}$ signal, resulting from centuries of MDN inputs, may persist for at least two decades following a reduction in MDN inputs. It is also possible that, during the carcass manipulation period, the depleted bank received enough MDN to maintain an elevated $\delta^{15} \mathrm{~N}$ signal. Possible sources include carcasses deposited beyond our reach by bears, or dissolved nutrients in hyporheic flows, which are likely to be more important in years of high salmon escapement, when a greater proportion of salmon biomass will decompose in the stream rather than being removed by bears (O'Keefe and Edwards 2002, Helfield and Naiman 2006).

Foliar $\mathrm{N}$ concentration did not increase on the enhanced bank (multiple linear regression indicated that $\mathrm{DBH}$ was the only significant variable affecting $\mathrm{C}: \mathrm{N}$ ) but this does not preclude a fertilization effect. Previous studies have reported inconsistent responses to experimental fertilization with respect to $\mathrm{N}$ concentrations in twigs and foliage, even where growth responses are positive (Bryant 1987, Drake et al. 2006). This can happen when fertilized plants undergo rapid growth to the extent that increases in biomass offset increases in $\mathrm{N}$ content. In such cases, $\mathrm{N}$ concentrations will remain constant or even decrease, despite an increase in $\mathrm{N}$ uptake (Bryant 1987). It is also possible that $\mathrm{N}$ is not the limiting nutrient for these trees. $\mathrm{N}$ is generally limiting in boreal forests, but other nutrients can be limiting or colimiting in some areas (Uliassi and Reuss 2002, Menge et al. 2012). The increase in spruce growth that we observed on the enhanced bank may be in response to additions of $\mathrm{P}$, calcium $(\mathrm{Ca})$, or magnesium $(\mathrm{Mg})$, which are also delivered to streams and riparian forests via salmon carcasses (Drake et al. 2005), but are not as easily traced using stable isotopes. These nutrient inputs could increase rates of $\mathrm{N}$ uptake by stimulating microbial activity and promoting mineralization of organic $\mathrm{N}$ in carcasses and surrounding soils, which could lead to significant uptake of MDN (and correspondingly increased foliar $\delta^{15} \mathrm{~N}$ ), even if total $\mathrm{N}$ uptake is not increased.

Prior to and during the carcass manipulation period, BAI was generally greater on the right (depleted) bank, likely because it faces south. In boreal forests of Alaska, aspect influences patterns of solar radiation; south-facing slopes typically exhibit warmer soils, increased rates of organic matter decomposition and nutrient cycling, longer growing 
seasons, and correspondingly greater forest production (Krause et al. 1959, Viereck 1975, Viereck et al. 1983). Growth rates were significantly lower on the left, northfacing bank prior to fertilization but were increased by the additions of salmon carcasses to the extent that they no longer differed significantly from those of the south-facing slope. The observed effect is also not likely to have been caused by differential competition between the banks, since forest composition and density did not differ between banks. We therefore conclude that the carcasses had the predicted effect of enhancing tree growth.

By transferring all carcasses to one bank, we essentially doubled the carcass density there, and one might question whether this treatment was excessive compared to the range of naturally occurring carcass depositions. Analysis of records provided by the Alaska Department of Fish and Game revealed that the fishery has taken about half the sockeye salmon returning to the Wood River system in general, including Hansen Creek, in most recent years (Kendall and Quinn 2009, Quinn et al. 2014a). Therefore, had there been no fishery and no experiment, the enhanced bank would have had about as many carcasses as it did in this study. However, it is important to note that carcasses in the water were moved into the riparian zone. In the water, they would have been decomposed by scavenging aquatic insects (Minakawa and Gara 1999, Winder et al. 2005) and bacteria. Dissolved nutrients may leach into hyporheic flows and be acquired by riparian trees (O'Keefe and Edwards 2002).

If exposed to the air, many carcasses are scavenged by blowflies, which are an important source of nutrient transfer in this system (Meehan et al. 2005), as are terrestrial insects elsewhere (Hocking and Reimchen 2006, Hocking et al. 2009). The proportion of carcasses that remains submerged (and thus unavailable for colonization by terrestrial insects) depends on stream habitat and source of mortality. More carcasses are submerged in deeper streams than shallow ones, and salmon dying of senescence are more often submerged than are bear-killed salmon, which may be moved to the riparian zone (Meehan et al. 2005). Specifically, carcass surveys at Hansen Creek revealed $35 \%$ on land, $44 \%$ partially submerged, and 21\% fully submerged (Meehan et al. 2005). Combined data from Hansen Creek and six small streams nearby revealed $38 \%$ on land, $17 \%$ partially submerged, and $45 \%$ fully submerged (T. P. Quinn, unpublished records). Thus, without human intervention, in these small streams, many carcasses would be within the wetted width under most conditions. The extent of these transfer processes (bears and hyporheic flows) will vary among streams, and among years as a function of bear density and salmon abundance (Quinn et al. 2017). Flooding can also transfer carcasses to the forest (Ben-David et al. 1998). Hansen Creek has a lower gradient (7.7\% slope) than the average $(12.1 \%)$ of salmon streams in the Wood River system (Lisi et al. 2013) and is much less prone to flood than others. In general, higher predation and carcass transport by bears in Hansen Creek offsets the lack of carcass movement by floods, with respect to other streams in the basin.

In conclusion, our results provided strong, in situ experimental evidence for the effect of salmon carcasses on the growth of trees in the riparian zone. However, even two decades of heavy manipulation did not allow the growth of trees on the enhanced bank to surpass those on the depleted bank, so the effect must be considered in the context of all factors affecting growth. Nevertheless, these results contribute to the expanding body of evidence of the importance of salmon in aquatic (Janetski et al. 2009) and terrestrial (Hocking and Reynolds 2011) ecosystems. Woody debris plays an important role in the formation of habitat complexity in streams (Bilby and Ward 1991), which in turn can affect the density of juvenile salmonids (Murphy et al. 1986, Hicks et al. 1991, Roni and Quinn 2001). Therefore, enhanced tree growth from carcasses might lead, over long periods of time, to larger trees that would eventually recruit to the stream as woody debris, in a positive feedback (Helfield and Naiman 2001). The nature of our experimental approach (transfer of carcasses into the riparian zone) is consistent with the idea that bears mediate the role of salmon in aquatic and terrestrial ecosystems, as a keystone interaction (Helfield and Naiman 2006). The role that salmon play in their aquatic ecosystems and nearby riparian zones will depend on the features of those recipient ecosystems. Consequently, the application of our results to other systems considers the suite of terrestrial and aquatic sources of production in streams (Wipfli and Baxter 2010), and the many factors affecting the abundance of salmon (Quinn 2018) and growth of trees (Van Cleve et al. 1983).

\section{ACKNOWLEdGments}

The long-term research on sockeye salmon and their ecosystems in Bristol Bay has been funded by many entities but we especially thank the seafood processing industry for their consistent support over many decades. In the more recent decades, the research program as a whole has also received support from the NSF BioComplexity and also the Coupled Natural and Human Systems programs, the Gordon and Betty Moore Foundation, the Alaska Department of Fish and Game, and other sponsors as well. We thank Alexa Camaioni for careful work in preparing, crossdating, and measuring the increment core samples, and two anonymous reviewers for helpful input. The sampling on Hansen Creek for bear predation was initiated by the late Donald Rogers and Gregory Ruggerone, and we are grateful for their insights. The daily surveys (by three to five people) have involved far more individuals than we can name, but we thank most especially Gregory Buck, Harry Rich, Jr., Curry Cunningham, Chris Boatright, and Jackie Carter, and the undergraduate students in the Aquatic Ecological Research in Alaska classes. Throwing the estimated $267,620 \mathrm{~kg}$ of salmon tissue into the forest over the study period was no small task.

\section{Literature Cited}

Bartz, K. K., and R. J. Naiman. 2005. Effects of salmon-borne nutrients on riparian soils and vegetation in southwest Alaska. Ecosystems 8:529-545.

Ben-David, M., T. A. Hanley, and D. M. Schell. 1998. Fertilization of terrestrial vegetation by spawning Pacific salmon: the role of flooding and predator activity. Oikos 83:47-55.

Bilby, R. E., and J. W. Ward. 1991. Characteristics and function of large woody debris in streams draining old-growth, clear-cut, and second-growth forests in southwestern Washington. Canadian Journal of Fisheries and Aquatic Sciences 48:2499-2508.

Bilby, R. E., B. R. Fransen, and P. A. Bisson. 1996. Incorporation of nitrogen and carbon from spawning coho salmon into the trophic system of small streams: evidence from stable isotopes. Canadian Journal of Fisheries and Aquatic Sciences 53:164-173.

Bilby, R. E., E. W. Beach, B. R. Fransen, J. K. Walter, and P. A. Bisson. 2003. Transfer of nutrients from spawning salmon to riparian 
vegetation in western Washington. Transactions of the American Fisheries Society 132:733-745.

Bryant, J. P. 1987. Feltleaf willow-snowshoe hare interactions: plant carbon/nutrient balance and floodplain succession. Ecology 68:1319-1327.

Cederholm, C. J., D. B. Houston, D. L. Cole, and W. J. Scarlett. 1989. Fate of coho salmon (Oncorhynchus kisutch) carcasses in spawning streams. Canadian Journal of Fisheries and Aquatic Sciences 46:1347-1355.

Cunningham, C. J., G. T. Ruggerone, and T. P. Quinn. 2013. Size-selectivity of predation by brown bears depends on the density of their sockeye salmon prey. American Naturalist 181: 663-673.

Drake, D. C., and R. J. Naiman. 2007. Reconstruction of Pacific salmon abundance from riparian tree-ring growth. Ecological Applications 17:1523-1542.

Drake, D. C., R. J. Naiman, and J. M. Helfield. 2002. Reconstructing salmon abundance in rivers: an initial dendrochronological evaluation. Ecology 83:2971-2977.

Drake, D. C., J. V. Smith, and R. J. Naiman. 2005. Salmon decay and nutrient contributions to riparian forest soils. Northwest Science 79:61-71.

Drake, D. C., R. J. Naiman, and J. S. Bechtold. 2006. Fate of nitrogen in riparian forest soils and trees: an $15 \mathrm{~N}$ tracer study simulating salmon decay. Ecology 87:1256-1266.

Field, R. D., and J. D. Reynolds. 2011. Sea to sky: impacts of residual salmon-derived nutrients on estuarine breeding bird communities. Proceeding of the Royal Society B 278:3081-3088.

Field, R. D., and J. D. Reynolds. 2013. Ecological links between salmon, large carnivore predation, and scavenging birds. Journal of Avian Biology 44:9-16.

Gende, S. M., T. P. Quinn, and M. F. Willson. 2001. Consumption choice by bears feeding on salmon. Oecologia 127:372-382.

Gende, S. M., T. P. Quinn, M. F. Willson, R. Heintz, and T. M. Scott. 2004. Magnitude and fate of salmon-derived nutrients and energy in a coastal stream ecosystem. Journal of Freshwater Ecology 19:149-160.

Hartman, C. W., and P. R. Johnson. 1984. Environmental atlas of Alaska. Institute of Water Resources/Engineering Experiment Station. University of Alaska, Fairbanks, Alaska, USA.

Helfield, J. M., and R. J. Naiman. 2001. Effects of salmon-derived nitrogen on riparian forest growth and implications for stream productivity. Ecology 82:2403-2409.

Helfield, J. M., and R. J. Naiman. 2002. Salmon and alder as nitrogen sources to riparian forests in a boreal Alaskan watershed. Oecologia 133:573-582.

Helfield, J. M., and R. J. Naiman. 2006. Keystone interactions: salmon and bear in riparian forests of Alaska. Ecosystems 9:167180 .

Hicks, B. J., J. D. Hall, P. A. Bisson, and J. R. Sedell. 1991. Responses of salmonids to habitat changes. American Fisheries Society Special Publication 19:483-518.

Hilderbrand, G. V., T. A. Hanley, C. T. Robbins, and C. C. Schwartz. 1999a. Role of brown bears (Ursus arctos) in the flow of marine nitrogen into a terrestrial ecosystem. Oecologia 121:546-550.

Hilderbrand, G. V., C. C. Schwartz, C. T. Robbins, M. E. Jacoby, T. A. Hanley, S. M. Arthur, and C. Servheen. 1999b. The importance of meat, particularly salmon, to body size, population productivity, and conservation of North American brown bears. Canadian Journal of Zoology 77:132-138.

Hocking, M. D., and T. E. Reimchen. 2006. Consumption and distribution of salmon (Oncorhynchus spp.) nutrients and energy by terrestrial flies. Canadian Journal of Fisheries and Aquatic Sciences 63:2076-2086.

Hocking, M. D., and J. D. Reynolds. 2011. Impacts of salmon on riparian plant diversity. Science 331:1609-1612.

Hocking, M. D., R. A. King, and T. E. Reimchen. 2009. The ecology of terrestrial invertebrates on Pacific salmon carcasses. Ecological Research 24:1091-1100.
Hunt, W. G., B. S. Johnson, and R. E. Jackman. 1992. Carrying capacity for bald eagles wintering along a northwestern river. Journal of Raptor Research 26:49-60.

Janetski, D. J., D. T. Chalconer, S. D. Tiegs, and G. A. Lamberti. 2009. Pacific salmon effects on stream ecosystems: a quantitative synthesis. Oecologia 159:583-595.

Kendall, N. W., and T. P. Quinn. 2009. Effects of population-specific variation in age and length on fishery selection and exploitation rates of sockeye salmon (Oncorhynchus nerka). Canadian Journal of Fisheries and Aquatic Sciences 66:896-908.

Kirchhoff, M. D. 2003. Effects of salmon-derived nitrogen on riparian forest growth and implications for stream productivity: comment. Ecology 84:3396-3399.

Kline, T. C. J., J. J. Goering, O. A. Mathisen, P. H. Poe, and P. L. Parker. 1990. Recycling of elements transported upstream by runs of Pacific salmon: I. $\mathrm{d}^{15} \mathrm{~N}$ and $\mathrm{d}^{13} \mathrm{C}$ evidence in Sashin Creek, southeastern Alaska. Canadian Journal of Fisheries and Aquatic Sciences 47:136-144.

Krause, H. H., S. Regier, and S. A. Wilde. 1959. Soils and forest growth on different aspects in the Tanana watershed of interior Alaska. Ecology 40:492-495.

Larkin, G. A., and P. A. Slaney. 1997. Implications of trends in marine-derived nutrient influx to south coast British Columbia salmonid production. Fisheries 22:16-24.

Lisi, P. J., D. E. Schindler, K. T. Bentley, and G. R. Pess. 2013. Association between geomorphic attributes of watersheds, water temperature, and salmon spawn timing in Alaskan streams. Geomorphology 185:78-86.

MacAvoy, S. E., G. C. Garman, and S. A. Macko. 2009. Anadromous fish as marine nutrient vectors. Fishery Bulletin 107:165-174.

Mathewson, D. D., M. D. Hocking, and T. E. Reimchen. 2003. Nitrogen uptake in riparian plant communities across a sharp ecological boundary of salmon density. BioMed Central Ecology $3: 1-11$.

Meehan, E. P., E. E. Seminet-Reneau, and T. P. Quinn. 2005. Bear predation on Pacific salmon facilitates colonization of carcasses by fly maggots. American Midland Naturalist 153:142-151.

Menge, D. N. L., L. O. Hedlin, and S. W. Pacala. 2012. Nitrogen and phosphorus limitation over long-term ecosystem development in terrestrial ecosystems. PLoS ONE 7:e42045.

Minakawa, N., and R. I. Gara. 1999. Ecological effects of a chum salmon (Oncorhynchus keta) spawning run in a small stream of the Pacific Northwest. Journal of Freshwater Ecology 14:327-335.

Murphy, M. L., J. Heifetz, S. W. Johnson, K. V. Koski, and J. F. Thedinga. 1986. Effects of clear-cut logging with and without buffer strips on juvenile salmonids in Alaskan streams. Canadian Journal of Fisheries and Aquatic Sciences 43:1521-1533.

Nadelhoffer, K. J., and B. Fry. 1994. Nitrogen isotope studies in forest ecosystems. Pages 22-44 in K. Lajtha and R. H. Michener, editors. Stable isotopes in ecology and environmental science. Blackwell, London, UK.

Naiman, R. J., J. M. Helfield, K. K. Bartz, D. C. Drake, and J. M. Honea. 2009. Pacific salmon, marine-derived nutrients, and the characteristics of aquatic and riparian ecosystems. American Fisheries Society Symposium 69:395-425.

Nislow, K. H., and B. E. Kynard. 2009. The role of anadromous sea lamprey in nutrient and material transport between marine and freshwater environments. American Fisheries Society Symposium 69:485-494.

O'Keefe, T. C., and R. T. Edwards. 2002. Evidence for hyporheic transfer and removal of marine-derived nutrients in a sockeye stream in southwest Alaska. American Fisheries Society Symposium 33:99-107.

Owens, N. J. P. 1987. Natural variations in ${ }^{15} \mathrm{~N}$ in the marine environment. Advances in Marine Biology 24:389-451.

Pess, G. R., T. P. Quinn, D. E. Schindler, and M. C. Liermann. 2014. Freshwater habitat associations between pink (Oncorhynchus gorbuscha), chum (O. keta), and Chinook salmon $(O$. tshawytscha) in a watershed dominated by sockeye salmon $(O$. nerka) abundance. Ecology of Freshwater Fish 23:360-372. 
Phipps, R. L. 1985. Collecting, preparing, crossdating, and measuring tree increment cores. U.S. Geological Survey Water-Resources Investigations Report 85-4148. USGS, Reston, Virginia, USA.

Pinay, G., T. O. O'Keefe, R. T. Edwards, and R. J. Naiman. 2003. Potential denitrification activity in the landscape of a Western Alaska drainage basin. Ecosystems 6:336-343.

Quinn, T. P. 2018. The Behavior and Ecology of Pacific Salmon and Trout. Second edition. University of Washington Press, Seattle, Washington, USA

Quinn, T. P., and G. B. Buck. 2001. Size and sex selective mortality on adult Pacific salmon: bears, gulls and fish out of water. Transactions of the American Fisheries Society 130:995-1005.

Quinn, T. P., S. M. Carlson, S. M. Gende, and H. B. Rich. 2009 Transportation of Pacific salmon carcasses from streams to riparian forests by bears. Canadian Journal of Zoology 87:195-203

Quinn, T. P., C. J. Cunningham, J. Randall, and R. Hilborn. 2014a. Can intense predation by bears exert a depensatory effect on recruitment in a Pacific salmon population? Oecologia 176:445-456.

Quinn, T. P., A. J. Wirsing, B. Smith, C. J. Cunningham, and J. Ching. 2014b. Complementary use of motion-activated cameras and unbaited wire snares for DNA sampling reveals diel and seasonal activity patterns of brown bears foraging on adult sockeye salmon. Canadian Journal of Zoology 92:893-903.

Quinn, T. P., C. J. Cunningham, and A. J. Wirsing. 2017. Diverse foraging opportunities drive the functional response of local and landscape-scale bear predation on Pacific salmon. Oecologia $183: 415-429$.

R Core Team. 2015. R: a language and environment for statistical computing. R Foundation for Statistical Computing, Vienna, Austria. www.r-project.org

Reimchen, T. E., and C. H. Fox. 2013. Fine-scale spatiotemporal influences of salmon on growth and nitrogen signatures of Sitka spruce tree rings. BMC Ecology 13:38.

Reimchen, T. E., D. Mathewson, M. D. Hocking, J. Moran, and D. Harris. 2003. Isotopic evidence for enrichment of salmon-derived nutrients in vegetation, soil, and insects in riparian zones in coastal British Columbia. American Fisheries Society Symposium 34:59-69.

Roni, P., and T. P. Quinn. 2001. Density and size of juvenile salmonids in response to placement of large woody debris in western Oregon and Washington streams. Canadian Journal of Fisheries and Aquatic Sciences 58:282-292.
Ruggerone, G. T., R. Hanson, and D. E. Rogers. 2000. Selective predation by brown bears (Ursus arctos) foraging on spawning sockeye salmon (Oncorhynchus nerka). Canadian Journal of Zoology 78:974-981.

Schoeninger, M. J., M. J. DeNiro, and H. Tauber. 1983. Stable nitrogen isotope ratios of bone collagen reflect marine and terrestrial components of prehistoric human diet. Science 220:1381-1383.

Tillotson, M. D., and T. P. Quinn. 2017. Climate and conspecific density trigger pre-spawning mortality in sockeye salmon (Oncorhynchus nerka). Fisheries Research 188:138-148.

Twining, C. W., E. P. Palkovacs, M. A. Friedman, D. J. Hasselman, and D. M. Post. 2017. Nutrient loading by anadromous fishes: species-specific contributions and the effects of diversity. Canadian Journal of Fisheries and Aquatic Sciences 74:609-619.

Uliassi, D. D., and R. W. Reuss. 2002. Limitations to symbiotic nitrogen fixation in primary succession on the Tanana River floodplain. Ecology 83:88-103.

Van Cleve, K., L. K. Oliver, R. Schlentner, L. A. Viereck, and C. T. Dyrness. 1983. Productivity and nutrient cycling in taiga forest ecosystems. Canadian Journal of Forest Research 13:747-766.

Van Daele, M. B., C. T. Robbins, B. X. Semmens, E. J. Ward, L. J. Van Daele, and W. B. Leacock. 2013. Salmon consumption by Kodiak brown bears (Ursus arctos middendorffi) with ecosystem management implications. Canadian Journal of Zoology 91:164-174.

Viereck, L. A. 1975. Forest ecology of the Alaska taiga. Pages 1-22 in Proceedings of the Circumpolar Conference on Northern Ecology. National Research Council of Canada, Ottawa, Ontario, Canada.

Viereck, L. A., C. T. Dyrness, I. C. Van Cleve, and M. J. Foote. 1983. Vegetation, soils, and forest productivity in selected forest types in interior Alaska. Canadian Journal of Forest Research 13:703-720.

Willson, M. F., and K. C. Halupka. 1995. Anadromous fish as keystone species in vertebrate communities. Conservation Biology 9:489-497.

Winder, M., D. E. Schindler, J. W. Moore, S. P. Johnson, and W. J. Palen. 2005. Do bears facilitate transfer of salmon resources to aquatic macroinvertebrates? Canadian Journal of Fisheries and Aquatic Sciences 52:2285-2293.

Wipfli, M. S., and C. V. Baxter. 2010. Linking ecosystems, food webs, and fish production: subsidies in salmonid watersheds. Fisheries 35:373-387.

\section{SUPPORTING INFORMATION}

Additional supporting information may be found in the online version of this article at http://onlinelibrary.wiley.com/doi/10.1002/ecy. 2453/suppinfo

\section{Data Availability}

Data are available from the Dryad Digital Repository: https://doi.org/10.5061/dryad.2q2k0q5. 